\title{
Reappraising a wartime earthquake: the October 3, 1943 event in the southern Marches (central Italy)
}

\author{
Andrea Tertulliani, Viviana Castelli, Antonio Rossi, Maurizio Vecchi
}

Istituto Nazionale di Geofisica e Vulcanologia, Italy

\author{
Article history \\ Received July 17, 2014; November 10, 2014. \\ Subject classification: \\ Historical seismology, 1943 earthquake, Marches, central Italy.
}

\begin{abstract}
The earthquake of October 3, 1943, is an important event for characterization of hazard in central Italy, but none of the earlier studies provide an exhaustive description of its effects. The context in which the earthquake occurred was very complex and many relevant records were not available for consultation when the studies were made. This study set out to improve our understanding of the earthquake and its effects by giving special care to the interpretative problems deriving from the peculiar historical and seismological context of the 1943 earthquake, with reference to the possible interactions between earthquake damage and war damage, and between the effects of the 1943 earthquake and those of other local earthquakes occurred between 1936 and 1951. The historical data set collected by earlier studies was critically revised and more data were sought in repositories that had not been previously considered. The number of localities for which a macrosesmic intensity can be assessed increased from 131 to 170. All intensity values were reassessed; from these we calculate a new macroseismic magnitude Mw 5.5 of the October 3, 1943, earthquake.
\end{abstract}

\section{Introduction}

The Italian administrative region known as le Marche (the Marches) is a stretch of country that lies between the central Adriatic coast and the Apennines. Seismicity tends to be most significant and frequent in the Apenninic chain that forms the western border of the Marches, and along the northern portion of the Adriatic coast, while in the southern coastal sector of the region is relatively low. The most notable exception to this general pattern of regional seismicity is the earthquake of October 3, 1943, located in the southern Marches, midway between the Apennines and the sea (Figure 1). All Italian parametric earthquake catalogs from the earliest [Postpischl 1985] to the latest [Rovida et al. 2011] - agree on identifying the October 1943 earthquake as the strongest recorded in that part of the Marches. This earthquake sets the benchmark for all hazard assessment and civil protection undertakings on a provincial scale and therefore it is very important to have as comprehensive and reliable a view of its impact as possible. The October 1943 earthquake was studied several times in the last thirty years [Raccichini 1984, Raccichini et al. 1985, Boschi et al. 1997, Boschi et al. 2000, Guidoboni et al. 2007] but never exhaustively. One reason for this is that many potentially relevant archival records were not available for consultation when the studies were made. However, the hardest obstacle to an exhaustive reconstruction of the October 1943 earthquake is the peculiar historical context in which it took place, at the start of the last and direst stage of the 2nd World War in peninsular Italy. For a couple of years after the October 1943 earthquake, the affected area was under military occupation and the scene of land-and air-warfare. In many of the affected localities, no formal assessment of damage was made until some time after the war ended (April 1945), when it must have been difficult to distinguish the damage caused by the earthquake from that caused by war, lack of repairs, and weather. Moreover, other sizable earthquakes occurred between 1936 and 1951 (Table 1) in or near the same area affected by the October 1943 earthquake; their effects could have enhanced and/or distorted the perception of the effects of the October 1943 earthquake. This study is the first that attempts to take into account these considerations. To reach a better understanding of the October 1943 earthquake, we carried out a critical revision of the historical sources quoted by earlier studies and started a new investigation of as many possible of the available repositories of 


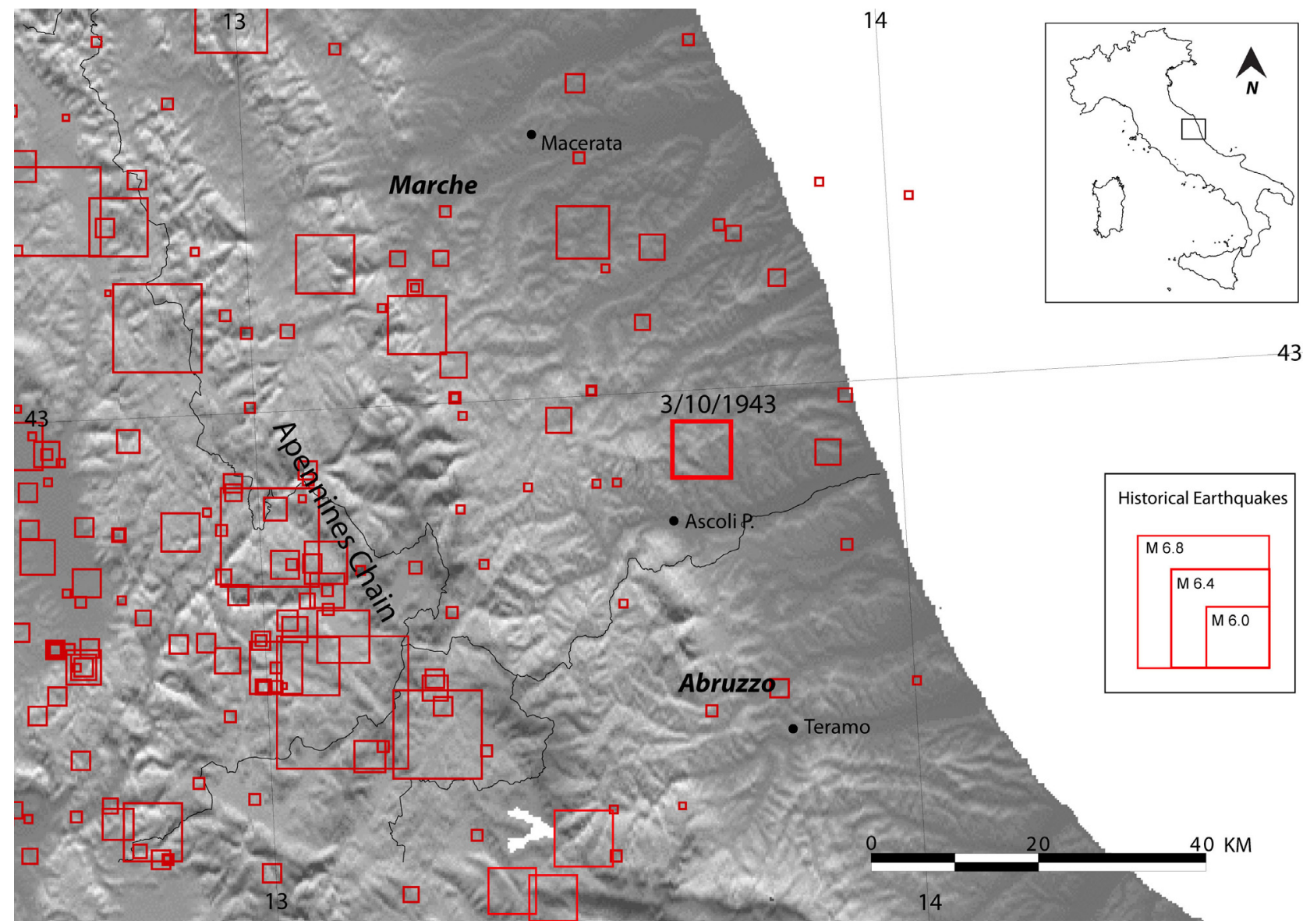

Figure 1. Historical seismicity of central-eastern Italy from CPTI11 [Rovida et al. 2011]. The October 3, 1943, earthquake is indicated with a bold line square.

historical data, with particular attention for those that earlier studies had not been able to consider but have become available for consultation at a later date. The results of this work allow to bring into better focus an earthquake of regional importance and to improve the characterization of its epicentral parameters.

\section{An overview of earlier studies of the October 3, 1943 earthquake}

Figure 2 shows the sources considered by earlier studies of the 1943 earthquake and the relationship between these studies and the parametric catalogues that used them as their references. The earliest historical-

\begin{tabular}{|c|c|c|c|c|}
\hline date & Imax & $\mathbf{I}_{0}$ & Mw & source \\
\hline December 9, 1936 & 7.5 & 6.5 & 4.8 & CPTI11, Rovida et al. 2011 \\
\hline December 19, 1941 & 7 & 6.5 & 5.0 & Tertulliani et al. 2008 \\
\hline January 29, 1943 & 7 & 6.5 & 4.9 & Tertulliani et al. 2008 \\
\hline March 25, 1943 & 7 & 6 & 5.0 & Tertulliani et al. 2008 \\
\hline September 5, 1950 & 8 & 8 & 8 & CPTI11, Rovida et al. 2011 \\
\hline August 8, 1951 & 7 & 7 & 5.3 & CPTI11, Rovida et al. 2011 \\
\hline September 1, 1951 & 7 & 7 & 5.3 & CPTI11, Rovida et al. 2011 \\
\hline
\end{tabular}

Table 1. List of the earthquakes occurred in the study area in a range of fifteen years around the 1943 event. The events are those in Figure 6. Maximum intensities, epicentral intensities and macroseismic magnitudes are indicated for each event. 


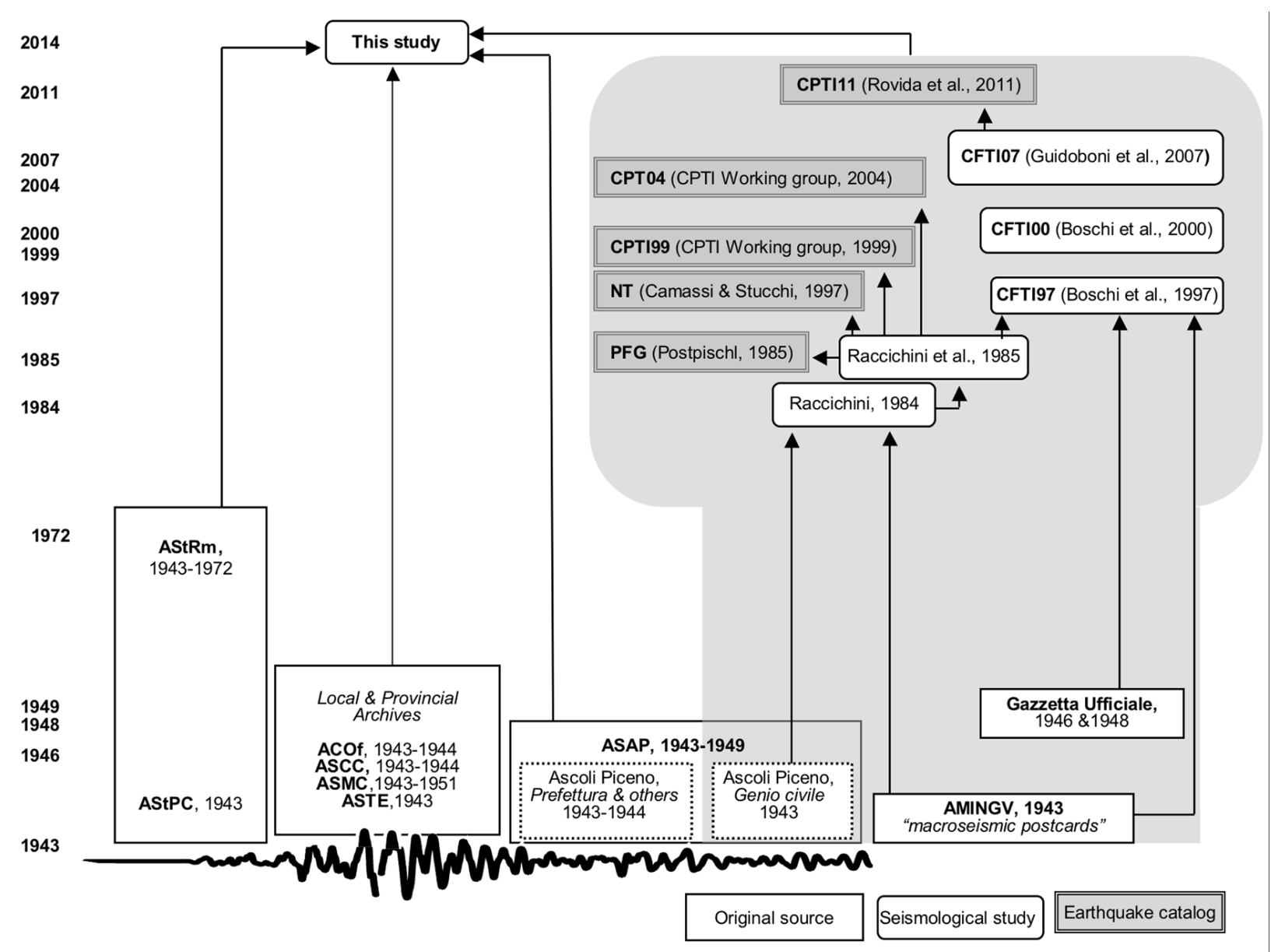

Figure 2. Sources used by earlier studies of the October 3, 1943 earthquake (shaded) and by this study.

seismological studies of the 1943 earthquake [Raccichini 1984, Raccichini et al. 1985] relied heavily on original historical sources; in their turn, early studies became major secondary sources of information for later studies [Boschi et al. 1997, 2000, Guidoboni et al. 2007]. Raccichini et al. [1985] present a total of 86 intensity points with maximum intensity IX MCS-Mercalli-Cancani-Sieberg assessed for the rural hamlet of San Venanzo. As Figure 3a shows, most of these data points (and almost all those above the damage threshold) are within the limits of the Ascoli Piceno province. The reason for this becomes clear if one consider that - apart from a few "macroseismic cards" [AMINGV 1943] and from eyewitnesses' verbal accounts (collected in 1985) - the most relevant historical source available to Raccichini et al. [1985] was a set of damage surveys carried out by the Civil Engineering Department (Genio Civile) of the Ascoli Piceno province [ASAP 1943a,b], pertaining to the territory of that single province. It is reasonable to assume that, if it had been possible to consult similar documents from other territories, the resulting distribution of macroseismic effects would have been different. Later studies of the October 1943 earthquake [Boschi et al. 1997, 2000, Guidoboni et al. 2007] relied to a large extent on the findings by Racci- chini. Guidoboni et al. [2007] underline that "the research on journalistic sources was unsuccessful" and that "the investigation at the Archivio Centrale dello Stato revealed a lack of documentation from July 1943 to the whole 1944". In spite of this, the number of localities for which Guidoboni et al. [2007] provide a macroseismic intensity value rises to 131 (Figure $3 b$ ), mainly due to the addition of 47 localities whose names are included in the lists of places entitled to claim compensation for earthquake damage by two decrees emanated by the Italian government in 1946 and 1948 and published in the Italian Official Gazette [Gazzetta ufficiale della Repubblica Italiana, 1946a-b-c; 1948]. Guidoboni et al. [2007] state that "A description of effects is not available" for these 47 localities. It appears that a space/time criterion was followed to assess intensities in these cases: the localities included in the 1946 Gazzetta Ufficiale list were given intensity VII-VIII MCS (if located roughly within $20 / 25 \mathrm{~km}$ from the epicenter) or VI-VII MCS (if located farther); the localities quoted in the 1948 Gazzetta Ufficiale list were given intensity VI MCS. For another 41 localities, already included in the Raccichini et al. [1985] intensity table, Guidoboni et al. [2007] give the same intensities as Raccichini et al. [1985], commenting that "in their case the study by 

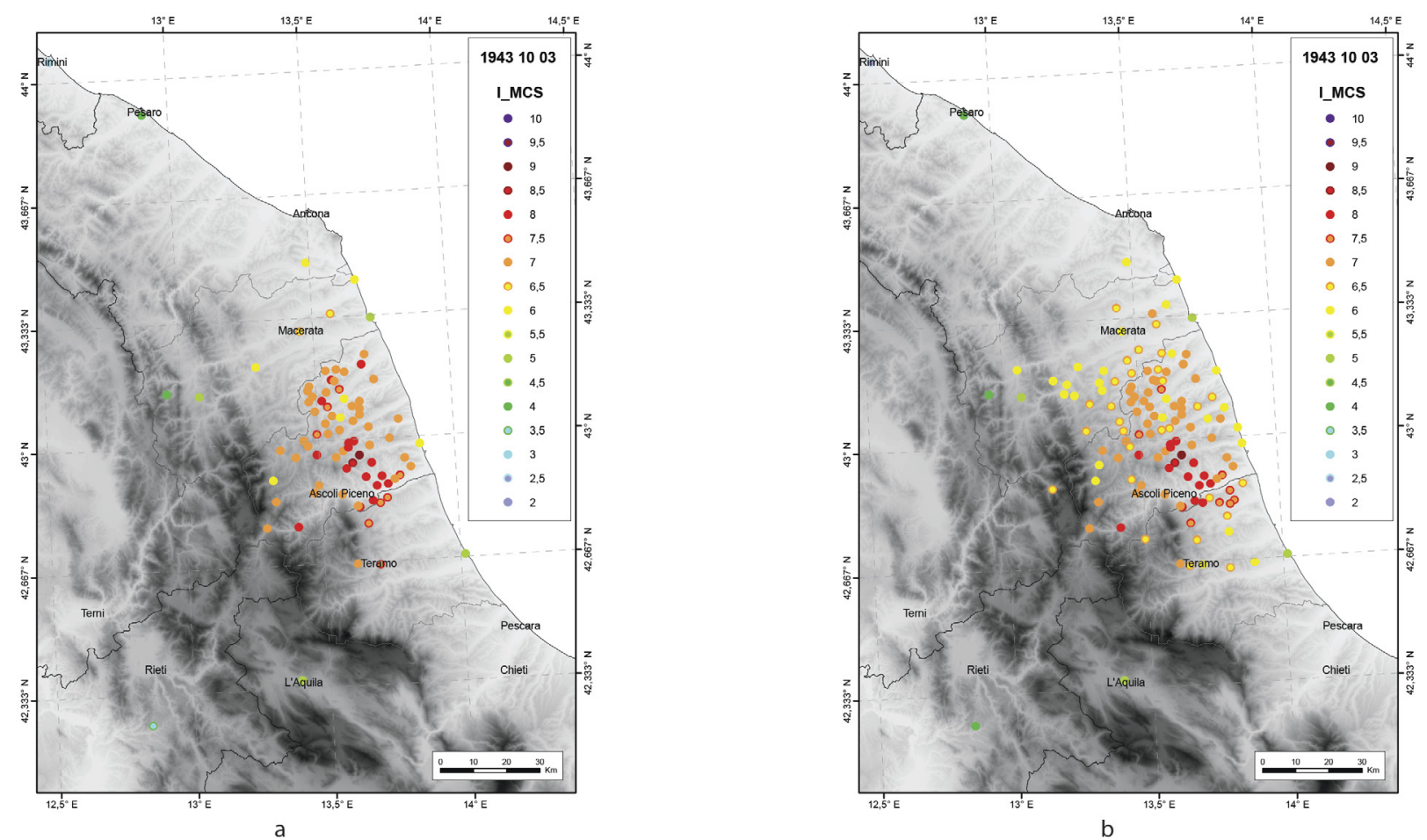

Figure 3. Intensity map of the October 3, 1943 earthquake after a) Raccichini et al., 1985; b) Guidoboni et al. [2007]. The provincial borders drawn in figure are those currently effective in 1943.

Raccichini et al. [1985] did not provide any description of the effects". However, these descriptions are provided by Raccichini [1984]. This overview of earlier studies and their sources shows that the quality of the historical data set on which the studies rely is less than satisfactory. Is there any room for improving it by launching a more comprehensive survey of potentially available historical sources? We consider the potential reliable historical sources for an event of that particular period.

\section{Historical context and historical records of the October 1943 earthquake}

Written evidence of how buildings were affected by an earthquake is the main ingredient for the assessment of macroseismic intensity data from which to derive reliable epicentral parameters of historical earthquakes. Normally, an Italian earthquake of the 1930s-1940s would have set in motion the production of written records of many kinds: cartoline macrosismiche (macroseismic cards), i.e. short, standard descriptions of earthquake effects, written on postcards by members of the official Italian network of seismic observators [Camassi 1991]; reports and damage surveys produced by public and private bodies; press articles and private memoirs. In each Italian province affected by an earthquake, the main public officers involved in producing these data would include: the Prefetto (main representative of the State), acting as a general manager and liaison officer between the local administrators and the central government in Rome, and the Ingegnere capo del Genio Civile (Head Civil Engineer of the Province), acting as responsible for the upkeep of public buildings and infrastructures and the management of claims for compensation on account of damage caused by natural events. Another routinely involved official would be the regional Soprintendente ai monumenti (Superintendent for the monuments), who was entrusted with the protection and maintenance of public and private buildings of artistic/historical value, with the help of local Ispettori onorari (honorary inspectors) who acted as the Superintendent's "eyes" in each of the communes belonging to the regional territory. In time, all or most of the records produced by these officials would have been filed away in public archives and made available to historians. Unfortunately, as noted, the 1943 earthquake occurred in far from normal circumstances. Up to a few days before its date, Italy had been an united kingdom. In 1940 the Italian kingdom, then ruled by King Victor Emmanuel III, under the control of Prime Minister and de facto dictator Benito Mussolini, had sided with Nazist Germany in the 2nd World War. In the summer of 1943 the Allied forces began their invasion of Italy and Mussolini was demoted (July 25). After a brief interval during which German troops started pouring into Italy from the north and Allied troops reached the southern end of the Italian penin- 
sula, the new Italian government secretly signed (September 3) an armistice with the Allied Powers that was made public on 8 September. Immediately afterward, the German troops already in Italy occupied the northern and central part of the country, setting it up (September 28) as a client state of Germany presided over by Mussolini, the Repubblica Sociale Italiana (RSI). Less than a week later, the earthquake occurred at the southern end of the newly-made Republic. The RSI took over the existing bureaucratic structures without introducing any relevant changes in their operational procedures. The official response to the October 1943 earthquake thus followed established routines of emergency relief and damage assessment, but rescuers and damage assessors had to cope with the obstacles generated by the ongoing state of war. For example, the population in need of temporary housing was much larger than normal, because many sfollati (refugees) from major Italian cities had settled in the area; also, the earthquake affected buildings whose vulnerability was enhanced by poor maintenance and by wartime bombings. Thanks to the truly heroic efforts of a few dedicated civil servants, official surveys of damage were started shortly after the earthquake. This earliest stage of field survey - carried out in spite of the lack of facilities (cars, petrol, and even paper were in short supply) and even to notable personal risk of the involved officials - was fast and preliminary, limited to the most damaged localities (identified as those where casualties had occurred) and ended in early 1944. After the war, between the end of 1945 and the beginning of 1946, new claims for compensation were made by other localities and there was a second stage of damage survey that went on roughly until 1949. The fact that, in many cases, assessment of damage was only carried out either after the passage of the front (1944) or after the war (1946), meant that earthquake damage can have been severely altered by subsequent acts of war, by adverse climatic condition and by lack of maintenance. For those reasons, many postwar claims for damages were not due to the 1943 earthquake only, as some of them say explicity (examples in Figures 4-5). Other written sources that would normally be produced in the wake of an earthquake of the early 1900s (local newspaper accounts, seismic bulletins, earthquake studies) were not produced at all in this case. The last of the weekly seismic bulletins issued by the Istituto Nazionale di Geofisica in 1943 covered the period from August 29 to September 4. Most local newspapers, such as the Ascoli-printed Vita Picena, that reported local seismicity up to April 1943 [Vita Picena 1943], seem to have suspended publication some time before the

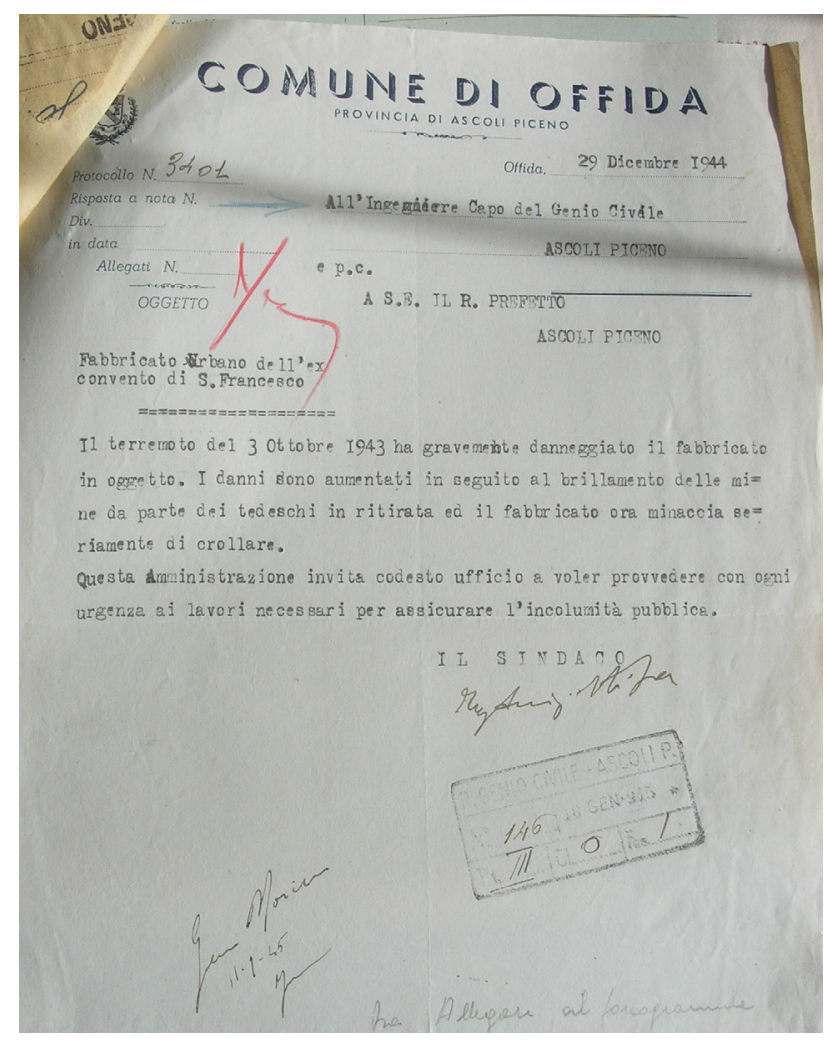

Figure 4. The Mayor of Offida describes the damage incurred by the San Francesco monastery to the Head Engineer of the Genio Civile of Ascoli Piceno, [ASCOf 1943-1944]. Translation: "The October 3, 1943 earthquake seriously damaged the aforesaid building. The damage increased after the setting off of the mines laid by the German army during its retreat" .

earthquake, owing to paper shortage. A few national newspapers were still in print at the time (we checked Il Messaggero, of Rome and La Stampa, of Turin), but they did not publish any accounts of the October 3, 1943, earthquake. Another complicating factor for the interpretation of damage reports derives from the plentiful local seismic activity of the period 1936-1951 (Figure 6, Table 1) including several damaging events, which further blurred the overall picture of the effects and the historical memory of local witnesses [Tertulliani et al. 2006, 2008]. Indeed, contemporary earthquake records occasionally mention earlier quakes that occurred between December 1941 and March 1943 [Tertulliani et al. 2008] with intensities ranging between VI and VII, while later records often mix up the effects of the October 1943 earthquakes with those of the 1950 and 1951 earthquakes [Tertulliani et al. 2006] with intensities up to VIII.

\section{Looking for new sources}

Given the poor historical background of the intensity values assessed for many of the localities quoted in the reference study of CPTI11 [Rovida et al. 2011] for the October 1943 earthquake, we undertook a new and thorough historical investigation with the aim of improving the state of knowledge. In doing this, we profited to a 


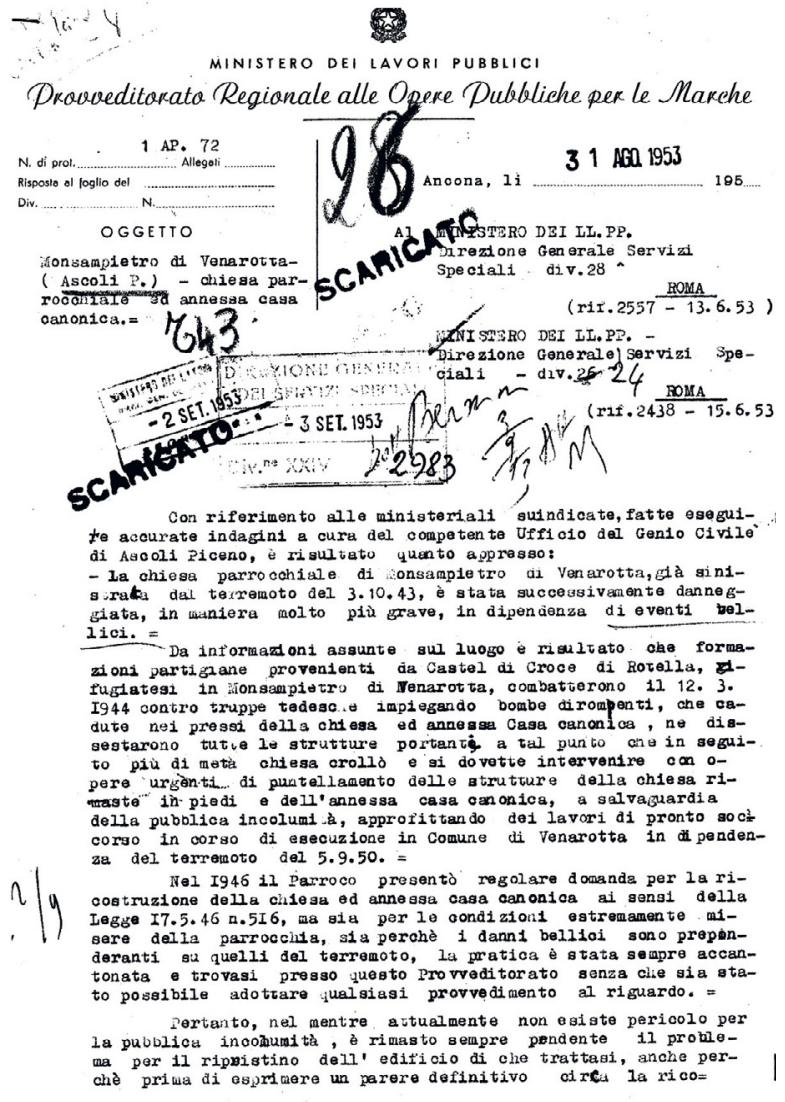

Figure 5. The damage history of the parish church of Monsampiero di Venarotta in a report sent by the Board for Public Works of the Regione Marche to the Ministry for Public Works on August 31, 1953 [AStRM, 1943-1972]. Translation: "After careful investigation by the Genio Civile of Ascoli Piceno, it results as following: the parish church of Monsampietro di Venarotta, damaged by the earthquake of 3-10-1943, has later ravaged in a much more severe manner, by war activities. From local information we know that Partisans from Castel di Croce di Rotella, [...] fighted on the 12-03 1944 against the German army using block-busters, which, falling near the church, compromised the structures to such an extent that half of the church collapsed [...], we had to intervene with urgent supports [...] taking advantage of the first aid activities after the 5-9-1950 earthquake. In 1946 the parish priest claimed for a reconstruction of the church [...] but both for the poor condition of the building and for war damage prevailed on earthquake damage, the dossier has always been set aside $[\ldots]$.

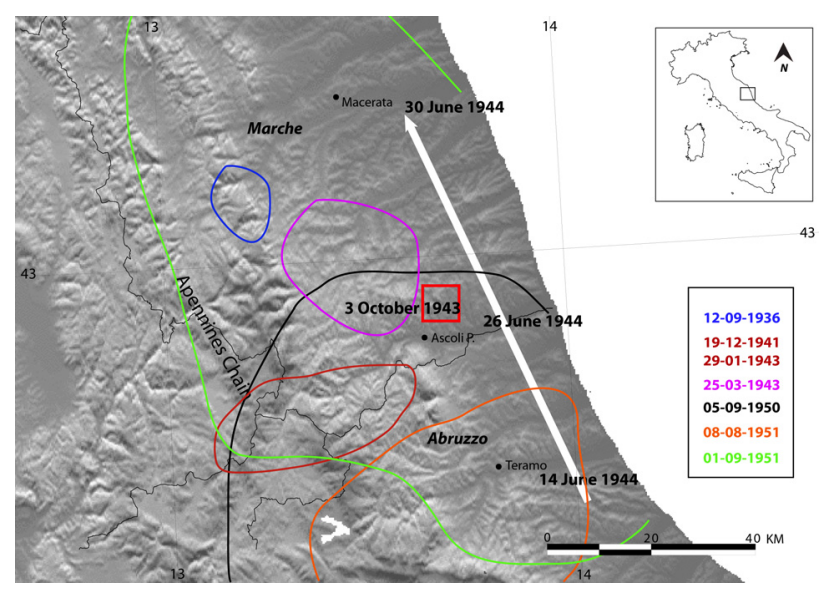

Figure 6. Location of the October 3, 1943 event (red square) with respect to the areas affected by damage caused by other earthquakes occurred in the region between 1936 and 1951 (indicated with colors in legend). The white arrow shows the progress of the war front line between 1943 and 1945, with the liberation dates for Teramo, Ascoli Piceno and Macerata. great extent from the fact that, in recent years, a number of archive holdings pertaining to public offices of the earthquake-affected area were transferred for permanent preservation to the Archivi di Stato. For instance, the Archivio di Stato of Ascoli Piceno at present holds a larger amount of Genio civile records than it possessed in the early 1980s, when the Raccichini studies were carried out. Also, the restrictions limiting access to some archive holdings, for example those of the Prefettura of Ascoli Piceno, have been recently lifted. Our initial investigation was carried out in the Archivio centrale dello Stato of Rome [ACS 1940-1945], and the public archives of Ascoli Piceno [ASAP 1943a,b], Teramo, [ASTe 1943-1957], Macerata [ASMc 1943-1957], and Rieti [ASRi 1945-1954]. The most significant accounts of earthquake effects were found in the holdings of the Genio Civile of Ascoli Piceno and Teramo archives [ASAP 1943a, ASTe 1943], while the Perugia archive does not hold any document related to the 1943 earthquake. An important 1943 file, including many records related to the immediate aftermath of the earthquake was found in the historical archives of the Dipartimento Nazionale di Protezione Civile in Rome [ASPC 1943]. We consulted, without finding any evidence of earthquake damage, the Aereofototeca e fototeca of the Istituto Centrale per la Conservazione Documentaria, where aerial photos taken by Royal Air Force during bombings are stored. At a further stage of the investigation, we focused on archives and public libraries of the municipalities of the epicentral area, looking for local histories and details on wartime life [ACAT 1943-1949, ACQT 1944, ACC 1943-1949, ACCa 1943-1949, ACCT 1943-1947, ACF 1943, ACR 1943]. The list of repositories and archives investigated is shown in Table 2 . The amount of historical data thus collected was huge: reports of damage to single buildings, lists of injuries and fatalities, compensation claims and much more.

\section{Data analysis and intensity assessment}

After collecting a set of historical earthquake data much larger than the one available to earlier studies, we were able to: first retrieve accounts of earthquake effects in several localities not considered by previous studies, and secondly improve the quality of information for those localities whose involvement in the earthquake had been deduced by previous studies from their mention in the Gazzetta Ufficiale. The reliability of single records of earthquake damage varies according to the degree of probability of their being "contaminated" by other kinds of damage, caused either by war events or by other earthquakes (see Figures 4-5). Therefore we ranked sources reliability according to their proximity to the date of the earthquake. Consequently, we grouped the collected information in three classes: 
Data repository (archive/library)

Roma
Archivio Centrale dello Stato
Dipartimento della Protezione civile
Ist. Centr. Cons. Doc. (Fototeca Nazionale; Aereofototeca
Nazionale)
Archivio storico del Messaggero
Archivio INGV
Biblioteca Nazionale

Ascoli Piceno

Archivio di Stato

Biblioteca Comunale

Perugia

Archivio di Stato

\section{Rieti}

Archivio di Stato

\section{Teramo}

Archivio di Stato

Biblioteca Provinciale

Archivio del Genio Civile

\section{Macerata}

Archivio di Stato

Biblioteca Comunale

Archivio Osservatorio Geofisico Sperimentale

\section{Ancona}

Soprintendenza ai beni architettonici ed archeologici delle Marche

Regione Marche

\section{Castignano}

Archivio Comunale

Offida

Archivio Comunale

\section{Appignano del Tronto}

Archivio Comunale

\section{Castorano}

Archivio Comunale

\section{Castel di Lama}

Archivio Comunale

\section{Colli del Tronto}

Archivio Comunale

\section{Folignano}

Archivio Comunale

\section{Rotella}

Archivio Comunale

\section{Cossignano}

Archivio Comunale

Table 2. List of the repositories and archives scrutinized during the research activity. In Italic those visited by the previous Authors.
(1) contemporary (records dated between October 3, 1943, and December 1945), considered very reliable;

(2) late (records dated between January 1946 and August 1950), of variable reliability. It is to be noted that, in 1946, local administrators called for new surveys of earthquake damage in those Communes that had not received any public aid to date;

(3) very late (records, dated from September 1950 up to the early 1970s), of little value except in cases where no earlier evidence of the October 1943 earthquake is available. It is to be noted that, earthquakes occurred in September 1950, and August-September 1951 involved more or less the same area affected by the 1943 earthquake, causing additional relevant damage.

To assess intensities we first considered only the information dated until 1945 (contemporary); failing that we did consider also the data filed in the late class and finally, only in those cases for which no better information was available, the data filed in the very late class. We assigned intensities using the MCS [Sieberg 1930] macroseismic scale. Our final intensity map is shown in Figure 7 and the complete list of intensity points is available in the Appendix. The maximum intensity (IX MCS) has been confirmed for the locality of San Venanzo, a frazione (hamlet) of the Commune of Castignano, where most houses collapsed killing 15 people. It is possible that the high intensity in San Venanzo, a small rural settlement, was the conse-

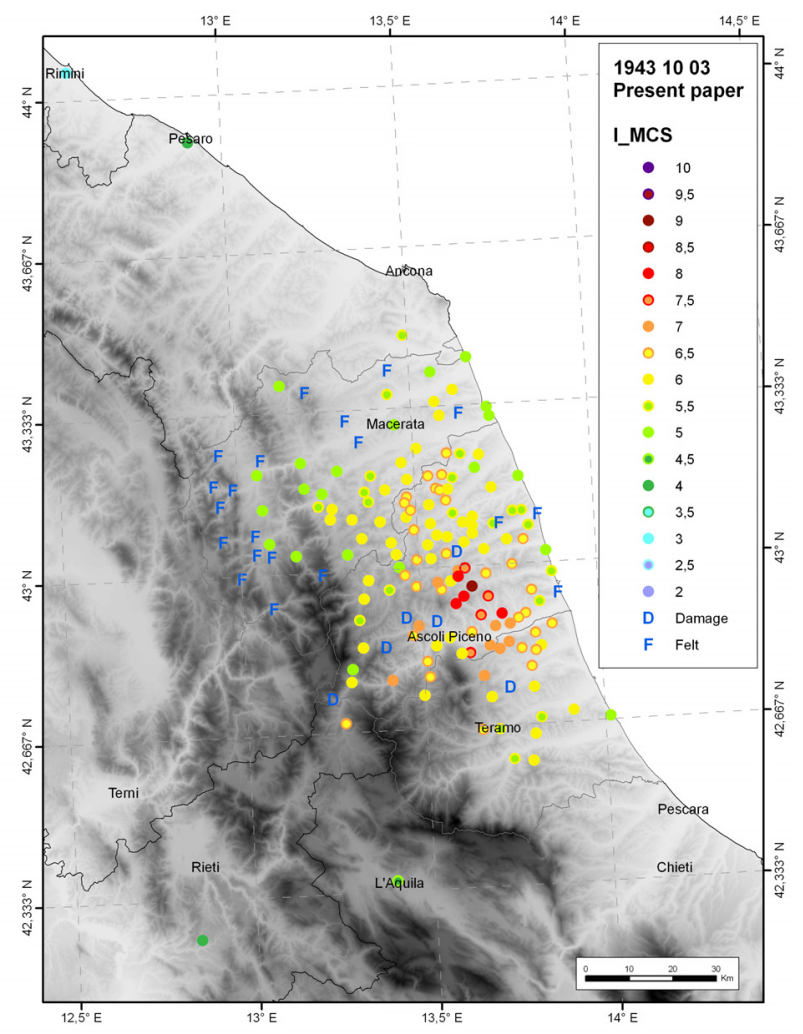

Figure 7. Intensity map resulting from the reappraisal carried out in the present work. 
quence of a locally high structural vulnerability, as already underlined by Castelli and Monachesi [1996]. A few other localities suffered very heavy damage (intensity VIIVIII and VIII), especially in the countryside (see appendix). After our revision the assessed intensities tend to drop: from 67 localities with I $\geq$ VII MCS [Guidoboni et al. 2007] to 19 in this study, and from 16 localities with I $\geq$ VIII MCS [Guidoboni et al. 2007] to 5 in this study (Figure 8). In 43 out of 47 cases for which Guidoboni et al. [2007] had assessed an intensity only on the basis of their being mentioned in the Gazzetta Ufficiale, unpublished contemporary evidence allows a more wellgrounded assessment of the macroseismic intensity to be made. In all, we were able to assess intensities from contemporary sources for 132 localities, while for another 38 localities we had to rely on late and very late accounts (Table 3). To understand if the contemporaneity of the sources potentially influences the intensity assessment, we selected the 105 localities for which we have both coeval and non coeval sources. To each locality we assigned an intensity based on the coeval accounts only (Ic), and another intensity based on non coeval accounts only (Inc). The difference Ic-Inc shows that the intensities assessed from late information only (Inc), with respect to the earthquake date, tend to be higher than those assessed from contemporary information (Ic) (Figure 9). This trend is consistent with expectations, given the disturbances (war, other earthquakes) that intervened after the October 3, 1943 earthquake (Figure 6), contributing to confuse earthquake effects, both physically (by adding together damage due to different causes) and in the people's memory. In particular the two later earthquakes that occurred on September 5, 1950 and September 1, 1951, affected the epicentral area of the 1943 event. This superimposition of effects and information was transferred in many official documents produced after the earthquake. Using the revised dataset of intensity points we are able to compute the macroseismic parametres of the earthquake, magnitude and epicentral coordinates. We used the Boxer 4.0 code [Gasperini et al. 2010], which allows to compute quantitative parametres of historical earthquakes (not only) from intensity datasets. The algorithm was the result of the analysis of the Italian macroseismic data-

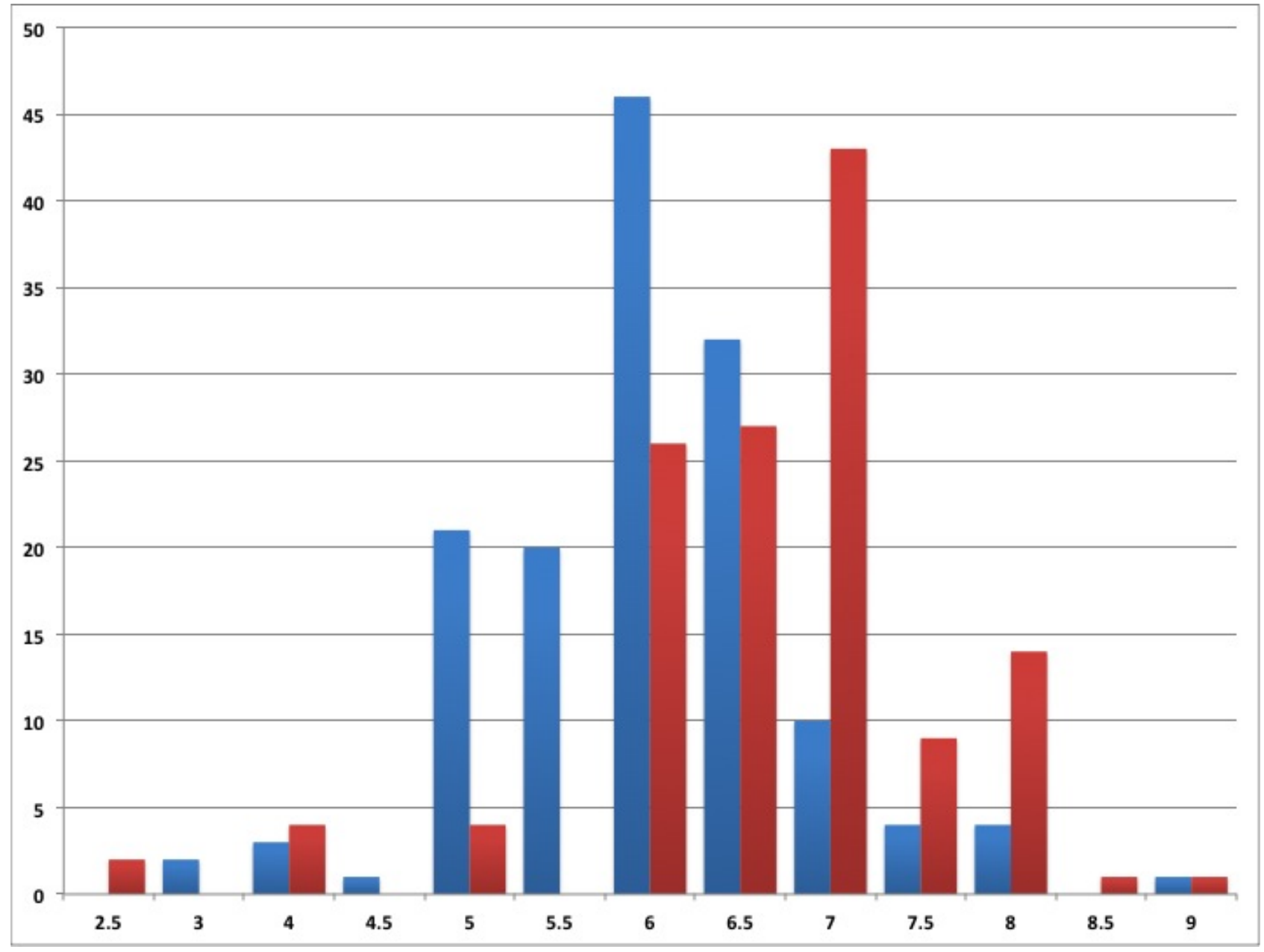

Figure 8. Comparison of the frequency distribution of intensities according to Guidoboni et al. [2007], in red, and to this study, in blue. It is notably evident the shifting of about one degree between the two distributions. 


\begin{tabular}{lccc} 
& $\begin{array}{c}\text { Number of } \\
\text { intensity data points }\end{array}$ & $\begin{array}{c}\text { Intensity assessed from early } \\
\text { data (1943-1945) }\end{array}$ & $\begin{array}{c}\text { Intensity assessed from late data } \\
(\mathbf{1 9 4 6} \text { onwards })\end{array}$ \\
\hline Guidoboni et al. 2007 & 131 & 77 & 54 \\
This study & 170 & 132 & 38 \\
\hline
\end{tabular}

Table 3. Synthesis of the comparison between the state of the art before and after this study.

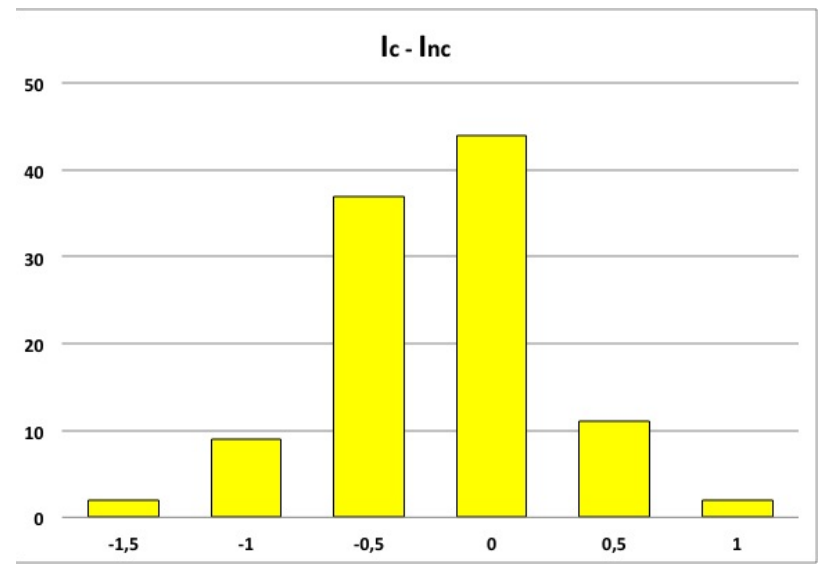

Figure 9. Residuals coeval intensity vs non coeval intensity, related to the 105 localities for with both coeval and non coeval sources are available.

base, and calibrated using earthquakes with known instrumental magnitudes. We calculated new parameters of the October 3, 1943 earthquake to the revised intensity data set (Table 4), obtaining a new Mw 5.5. Epicentral parametres did not change much from those proposed in previuos studies.

\section{Conclusions}

By retrieving and critically assessing the historical sources quoted by earlier studies of the October 3, 1943 earthquake and by carrying out a search for as many as possible "new" historical accounts, we achieved a considerable quantitative and qualitative improvement of the set of macroseismic historical data for this earthquake. The number of localities for which a macroseismic intensity could be assessed increased from 131 in Guidoboni et al. [2007] to 170 (Figure 8); all these intensities were assessed from actual descriptions of ef- fects. The newly-assessed macroseismic intensities tend to be lower than those assessed for the same localities by earlier studies. Intensities equal to or larger than VIII MCS have been assessed only for 5 localities (versus 16 in earlier studies), all of which are clustered in the area round the hamlet of San Venanzo, to which the maximum intensity (IX MCS) is assigned. The number of localities for which I $\geq$ VII MCS (indicative of significant damage) was assessed, drops from 67 to 19 . The geographical distribution of the intensity data points includes a cluster of damaged localities to the S-SW of the epicentral area (roughly on the border between the Marches and Latium). We suggest that, in spite of efforts to focus on reliable accounts, this cluster results from the superposition of the effects of the October 1943 earthquake on those caused, in the same area, by the December 1941 and March 1943 earthquakes [Tertulliani et al. 2008]. We calculate a macroseismically determined $\mathrm{Mw}$ by the application of the Boxer 4.0 code [Gasperini et al 2010] to the new collection of intensity points, with a resulting value of 5.5 , slightly lower than the 5.8 value proposed in CPTI11 [Rovida et al. 2011]. The epicentral coordinates do not change much from those proposed in CPTI11. Important biases in early intensity assessments, for past earthquakes have been already evidenced [Hough 2013, Tertulliani and Cucci 2014 among others]. This paper shows that a lack of completeness in the documentation of earthquakes can occur even in the case of nearly contemporary events. The period 1940-1950, just over the end of the 2nd World War, is characterized by a very poor reliability of the instrumental data, as well as of the macroseismic information [Tertulliani et al. 2008]. The comforting results of this and other researches in the same field

\begin{tabular}{lccc} 
& Mw & Lat & Long \\
\hline CPTI11, Rovida et al. 2011 & 5.8 & 42.909 & 13.651 \\
This study & 5.5 & 43.918 & 13.647
\end{tabular}

Table 4. Final earthquake parameters computed after this study, in comparison with the previous one quoted in the latest version of the CPTI11 Catalogue in Rovida et al. [2011]. 
[for instance Molin et al. 2008, Camassi et al. 2011] give encouragement to continue working in the field of historical seismology to improve the quality of historical macroseismic data.

Acknowledgements. We are grateful to the authors of earlier studies of the October 1943 earthquake, whose groundbreaking work was the starting point of this revision; to Flavio Gottardi for his great skill in exploring historical archives and his invaluable contribution to this study; to the personnel of the Archivi di Stato of Ascoli Piceno and Macerata, of the Genio Civile archive in Teramo, of the Soprintendenza per i beni architettonici e paesaggistici delle Marche archives of Ancona and of the municipal archives of Castignano and Offida. We are also in debt to Luca Arcoraci for drawing the intensity maps. Finally we thank Susan Hough, Luigi Cucci and two anonymous referees that helped improve this paper with their suggestions.

\section{References}

\section{Primary sources and official archive records}

ACAT (Archivio Comunale di Appignano del Tronto) (1943-1949). Correspondence, Cat. 15.

ACQT (Archivio Comunale di Arquata del Tronto) (1944). Correspondence.

ACS (Archivio Centrale dello Stato, Rome) (1940-1945). Ministero pubblica Istruzione, Dir. Gen. Antichità e Belle Arti, bb. 29, 30.

ACC (Archivio Comunale di Castignano) (1943-1949). Correspondence 17/10/1943-8/10/1949.

ACCa (Archivio Comunale di Castorano) (1943-1949). Cat. 13-15, b. 95

ACCT (Archivio Comunale di Colli del Tronto) (19431947). Correspondence Cat. 15.

ACF (Archivio Comunale di Folignano) (1943). Correspondence.

ACOf (Archivio storico comunale di Offida), (19431944). Correspondence, Cat. 10, b. 811.

ACOf (1943-1944) Registro delibere podestarili, n. 16 e 47.

ACR (Archivio Comunale di Rotella) (1943). Correspondence.

AMINGV (Archivio Macrosismico Istituto Nazionale di Geofisica e Vulcanologia) (1943). Cartoline macrosismiche.

ASAP (Archivio di Stato di Ascoli Piceno), (1943a). Genio civile. Miscellanea affari generali, bb. 7, 41, 42, 51, 52, 78, 102, 132, 136, 167, 192, 219).

ASAP (1943b) Prefettura Gabinetto, bb. 38, 44, 70, 78, $79,86$.

ASMc (Archivio di Stato di Macerata) (1943-1957)

Genio Civile bb. 7, 27, 70, 120, 145, 162.

ASPC (Archivio Storico della Protezione Civile) (1943),

Terremoto del 3 ottobre 1943.

ASRi (Archivio di Stato di Rieti) (1945-1954), Prefettura
Gabinetto, b. 43.

ASTe (Archivio di Stato di Teramo) (1943-1957), Genio Civile, bb. 1575, 1843, 3351, 3352, 3356, 3402, 3416, 3417, 3420, 3422, 3578, 3710, 3719, 3720, 3935, 3940.

ASTe (1943) Prefettura Gabinetto, bb. 44, 78, 79.

AStRM (Archivio storico Regione Marche) (1943-1972). Pratiche per richiesta risarcimento danni terremoti del 1943, 1950 e 1951, presentate a "Regione Marche, Assessorato ai Lavori Pubblici, Centro Operativo Sisma, Settore amministrativo".

Gazzetta ufficiale della Repubblica Italiana, (1946a). Regio decreto legislativo 17 maggio 1946, n.516, Disposizioni per la riparazione dei danni causati dal terremoto del 3 ottobre 1943 nei Comuni delle provincie di Ascoli Piceno, Macerata e Teramo.

Gazzetta ufficiale della Repubblica Italiana (1946b). Decreto ministeriale 12 agosto 1946, Approvazione dell'elenco dei comuni colpiti dal terremoto del 3 ottobre 1943 che vengono ammessi a beneficiare delle disposizioni del regio decreto legislativo 17 maggio 1946, n.516.

Gazzetta ufficiale della Repubblica Italiana (1946c). Decreto ministeriale 25 ottobre 1946, Approvazione dell'elenco dei comuni danneggiati dal terremoto del 3 ottobre 1943 nelle provincie di Ascoli Piceno e Teramo per l'osservanza delle norme tecniche di edilizia asismica.

Gazzetta ufficiale della Repubblica Italiana (1948). Decreto ministeriale 17 febbraio 1948, Elenco suppletivo dei Comuni colpiti dal terremoto del 3 ottobre 1943 ai quali sono applicabili le disposizioni del regio decreto legislativo 17 maggio 1946, n. 516.

Messaggero (Il), year 1943.

Stampa (La), year 1943.

Vita Picena (1943). Numbers 3 (Jan. 23), 6 (Feb. 6), 7 (Feb. 13), 14 (Apr. 3).

\section{Studies}

Boschi, E., E. Guidoboni, G. Ferrari, G. Valensise and P. Gasperini, eds. (1997). Catalogo dei forti terremoti in Italia dal 461 a.C. al 1980, voll. 2. ING-SGA, Bologna, 644 pp.

Boschi, E., E. Guidoboni, G. Ferrari, D. Mariotti, G. Valensise and P. Gasperini, eds. (2000). Catalogue of Strong Italian Earthquakes from 461 B.C. to 1980. Annali di Geofisica, 43 (4), 609-868.

Camassi, R. (1991). Bollettini sismici e studio dei terremoti dei secoli XIX e XX. In: P. Albini, M.S. Barbano (eds.), Macrosismica, Gruppo nazionale per la difesa dai terremoti, Atti del Convegno: Pisa, 25-27 giugno 1990, vol. 2, Bologna : 207-222. In Italian.

Camassi, R. and M. Stucchi (eds.) (1997) NT4.1 un catalogo parametrico di terremoti di area italiana al di 
sopra della soglia del danno. CNR-GNDT. http:/ / emidius.mi.ingv.it/NT/ (last accessed, November 2014). In Italian.

Camassi, R., V. Castelli, D. Molin, F. Bernardini, C. H. Caracciolo, E. Ercolani and L. Postpischl (2011). Materiali per un catalogo dei terremoti italiani: eventi sconosciuti, rivalutati o riscoperti, Quaderni di Geofisica, 96. In Italian.

Castelli, V. and G. Monachesi (1996). Problems of reliability in earthquake parameters determination from historical records. Annali di Geofisica, 39, 1029-1040.

CPTI Working Group (1999). Catalogo Parametrico dei Terremoti Italiani, vers. 1 (CPTI99), ING-GNDTSGA-SSN, Bologna, 92 pp., available at: http:/ / emi dius.mi.ingvit/CPTI (last accessed, November 2014). In Italian.

CPTI Working Group (2004). Catalogo Parametrico dei Terremoti Italiani, vers. 2004 (CPTI04), INGV, Bologna, available at: http: / / emidius.mi.ingv.it/CPTI04 (last accessed, November 2014). In Italian.

Guidoboni, E., G. Ferrari, D. Mariotti, A. Comastri, G. Tarabusi and G. Valensise (2007). Catalogo dei forti terremoti 461 a.C.-1997. http:/ / storing.ingv.it/ cfti4 med/ (last accessed, December 2011).

Gasperini, P, G. Vannucci, D. Tripone and E. Boschi (2010). The location and sizing of historical earthquakes using the attenuation of macroseismic intensity with distance, Bull. Seismol. Soc. Am., 100, 2035-2066; doi:10.1785/0120090330.

Hough, S.E. (2013). Spatial variability of "Did you feel it" intensity data: Insights into sampling biases in historical earthquake intensity distributions, Bull. Seismol. Am. Soc., 103, 2767-2781, doi: 10.1785/0120120285.

Molin, D., F. Bernardini, R. Camassi, C. H. Caracciolo, V. Castelli, E. Ercolani, L. Postpischl (2008). Materiali per un catalogo dei terremoti italiani: revisione della sismicità minore del territorio nazionale CD-Rom allegato, Quaderni di Geofisica, 57. In Italian.

Postpischl, D. (1985). Catalogo dei terremoti italiani dall'anno 1000 al 1980, CNR-PFG, Quaderni de «La ricerca scientifica», 114 2B, Bologna, 239 pp. In Italian.

Raccichini, S. (1984). Considerazioni sul terremoto del 3 ottobre 1943 nel Piceno. Proposte e ricerche, 13, 96-100. In Italian.

Raccichini, S., M. Stucchi and W. Calza (1985). The Castignano Earthquake of October 3, 1943. In: D. Postpischl (ed.), Atlas of isoseismal maps of Italian earthquakes. CNR-PFG, Quaderni de «La ricerca scientifica», 114 (2A), 144-145.

Rovida, A., R. Camassi, P. Gasperini and M. Stucchi (eds.) (2011). CPTI11, the 2011 version of the Parametric Catalogue of Italian Earthquakes. Milano, Bologna, http:/ / emidius.mi.ingv.it/CPTI
Sieberg, A. (1930). Geologie der Erdbeben, in Handbuch der Geophysik, 2 (4), 550-555.

Tertulliani, A., F. Galadini, F. Mastino, A. Rossi and M. Vecchi (2006). Studio macrosismico del terremoto del Gran Sasso del 5 settembre 1950, Il Quaternario, 19 (2), 195-214. In Italian.

Tertulliani, A., A. Rossi, V. Castelli, M. Vecchi and F. Gottardi (2008). Terremoti "dispersi" al confine tra Marche, Umbria e Lazio nel 1941-1943, Quaderni di Geofisica, 58. In Italian.

Tertulliani, A. and L. Cucci (2014). New insights on the strongest historical earthquake in the Pollino region (southern Italy), Seism. Res. Lett., 85 (3), 743-751; doi: $10.1785 / 0220130217$.

UCMEA (Ufficio centrale di Meteorologia ed Ecologia Agraria), (1943a). Bollettino Sismico Settimanale, 1308, 16-23 gennaio 1943, Roma.

UCMEA (1943b). Bollettino Sismico Settimanale, 1309, 24-31 gennaio 1943, Roma.

\footnotetext{
${ }^{\star}$ Corresponding author: Andrea Tertulliani, Istituto Nazionale di Geofisica e Vulcanologia, Sezione Roma 1, Rome, Italy; email: andrea.tertulliani@ingv.it.

(C) 2014 by the Istituto Nazionale di Geofisica e Vulcanologia. All rights reserved.
} 


\section{Appendix}

\begin{tabular}{|c|c|c|c|c|}
\hline locality & $\mathrm{pr}$ & lat & long & I MCS \\
\hline San Venanzo (Castignano) & AP & 42.957 & 13.647 & 9.0 \\
\hline Castignano & $\mathrm{AP}$ & 42.937 & 13.622 & 8.0 \\
\hline Castorano & AP & 42.898 & 13.727 & 8.0 \\
\hline Patrignone (Montalto delle Marche) & $\mathrm{AP}$ & 42.979 & 13.609 & 8.0 \\
\hline Ripaberarda (Castignano) & AP & 42.923 & 13.599 & 8.0 \\
\hline Appignano del Tronto & AP & 42.897 & 13.668 & 7.5 \\
\hline Folignano & AP & 42.820 & 13.633 & 7.5 \\
\hline Offida & AP & 42.935 & 13.691 & 7.5 \\
\hline Porchia (Montalto delle Marche) & AP & 42.996 & 13.630 & 7.5 \\
\hline Acquasanta & AP & 42.771 & 13.411 & 7.0 \\
\hline Ancarano & TE & 42.839 & 13.743 & 7.0 \\
\hline Castel di Lama & AP & 42.873 & 13.707 & 7.0 \\
\hline Civitella del Tronto & $\mathrm{TE}$ & 42.771 & 13.668 & 7.0 \\
\hline Colli del Tronto & AP & 42.876 & 13.748 & 7.0 \\
\hline Maltignano & $\mathrm{AP}$ & 42.833 & 13.689 & 7.0 \\
\hline Montalto delle Marche & AP & 42.991 & 13.610 & 7.0 \\
\hline Rovetino (Rotella) & AP & 42.969 & 13.551 & 7.0 \\
\hline Sant'Egidio alla Vibrata & $\mathrm{TE}$ & 42.825 & 13.715 & 7.0 \\
\hline Venarotta & AP & 42.881 & 13.493 & 7.0 \\
\hline Acquaviva Picena & $\mathrm{AP}$ & 42.944 & 13.813 & 6.5 \\
\hline Alteta (Montegiorgio) & $\mathrm{AP}$ & 43.163 & 13.559 & 6.5 \\
\hline Cerreto (Montegiorgio) & AP & 43.160 & 13.570 & 6.5 \\
\hline Colle di Funti (Ascoli Piceno) & $\mathrm{AP}$ & 42.807 & 13.511 & 6.5 \\
\hline Collegrato (Valle Castellana) & $\mathrm{TE}$ & 42.774 & 13.516 & 6.5 \\
\hline Colonnella & TE & 42.872 & 13.866 & 6.5 \\
\hline Controguerra & $\mathrm{TE}$ & 42.855 & 13.818 & 6.5 \\
\hline Cossignano & $\mathrm{AP}$ & 42.983 & 13.688 & 6.5 \\
\hline Force & AP & 42.963 & 13.491 & 6.5 \\
\hline Francavilla d'Ete & FM & 43.190 & 13.539 & 6.5 \\
\hline Magliano di Tenna & FM & 43.138 & 13.586 & 6.5 \\
\hline Massa Fermana & FM & 43.149 & 13.476 & 6.5 \\
\hline Massignano & $\mathrm{AP}$ & 43.050 & 13.798 & 6.5 \\
\hline Monsampolo del Tronto & AP & 42.897 & 13.794 & 6.5 \\
\hline Montappone & FM & 43.137 & 13.470 & 6.5 \\
\hline Monte Rinaldo & FM & 43.028 & 13.580 & 6.5 \\
\hline Monte San Giusto & MC & 43.236 & 13.595 & 6.5 \\
\hline Monte San Pietrangeli & FM & 43.191 & 13.578 & 6.5 \\
\hline Monte Vidon Corrado & FM & 43.121 & 13.486 & 6.5 \\
\hline Montefalcone Appennino & FM & 42.987 & 13.460 & 6.5 \\
\hline Nereto & TE & 42.819 & 13.817 & 6.5 \\
\hline Poggio Casoli (Accumuli) & RI & 42.687 & 13.274 & 6.5 \\
\hline Poggio di Bretta (Ascoli Piceno) & AP & 42.863 & 13.640 & 6.5 \\
\hline Ripatransone & AP & 42.999 & 13.762 & 6.5 \\
\hline Roccafluvione & AP & 42.861 & 13.475 & 6.5 \\
\hline Rotella & AP & 42.954 & 13.561 & 6.5 \\
\hline Santa Vittoria in Matenano & FM & 43.018 & 13.496 & 6.5 \\
\hline Sant'Omero & $\mathrm{TE}$ & 42.786 & 13.803 & 6.5 \\
\hline Servigliano & FM & 43.080 & 13.492 & 6.5 \\
\hline Spinetoli & AP & 42.888 & 13.773 & 6.5 \\
\hline Torano Nuovo & $\mathrm{TE}$ & 42.825 & 13.778 & 6.5 \\
\hline Torricella Sicura & $\mathrm{TE}$ & 42.659 & 13.656 & 6.5 \\
\hline Capodacqua (Arquata del Tronto) & AP & 42.738 & 13.239 & $\mathrm{D}$ \\
\hline Gaico (Roccafluvione) & AP & 42.840 & 13.397 & $\mathrm{D}$ \\
\hline Ortezzano & FM & 43.031 & 13.609 & $\mathrm{D}$ \\
\hline Palmiano & AP & 42.899 & 13.458 & $\mathrm{D}$ \\
\hline Venagrande (Ascoli Piceno) & AP & 42.889 & 13.543 & $\mathrm{D}$ \\
\hline Villa Camera (Campli) & TE & 42.745 & 13.739 & $\mathrm{D}$ \\
\hline
\end{tabular}

\begin{tabular}{|c|c|c|c|c|}
\hline locality & $\mathrm{pr}$ & lat & long & I MCS \\
\hline Amandola & FM & 42.980 & 13.357 & 6.0 \\
\hline Arquata del Tronto & $\mathrm{AP}$ & 42.771 & 13.296 & 6.0 \\
\hline Ascoli Piceno & $\mathrm{AP}$ & 42.853 & 13.578 & 6.0 \\
\hline Bellante & TE & 42.743 & 13.806 & 6.0 \\
\hline Belmonte Piceno & FM & 43.091 & 13.539 & 6.0 \\
\hline Campli & TE & 42.726 & 13.686 & 6.0 \\
\hline Camporotondo di Fiastrone & MC & 43.131 & 13.265 & 6.0 \\
\hline Canzano & TE & 42.646 & 13.804 & 6.0 \\
\hline Carassai & $\mathrm{AP}$ & 43.033 & 13.686 & 6.0 \\
\hline Cermignano & TE & 42.590 & 13.794 & 6.0 \\
\hline Cessapalombo & MC & 43.109 & 13.259 & 6.0 \\
\hline Corridonia & MC & 43.248 & 13.510 & 6.0 \\
\hline Corropoli & $\mathrm{TE}$ & 42.828 & 13.833 & 6.0 \\
\hline Falerone & FM & 43.107 & 13.472 & 6.0 \\
\hline Fermo & FM & 43.160 & 13.716 & 6.0 \\
\hline Grasciano (Notaresco) & TE & 42.691 & 13.914 & 6.0 \\
\hline Gualdo & MC & 42.882 & 13.166 & 6.0 \\
\hline Loro Piceno & MC & 43.166 & 13.416 & 6.0 \\
\hline Mogliano & MC & 43.185 & 13.479 & 6.0 \\
\hline Monsampietro Morico & FM & 43.066 & 13.556 & 6.0 \\
\hline Monte Giberto & FM & 43.091 & 13.631 & 6.0 \\
\hline Monte San Martino & MC & 43.030 & 13.439 & 6.0 \\
\hline Monte Vidon Combatte & FM & 43.050 & 13.631 & 6.0 \\
\hline Montedinove & $\mathrm{AP}$ & 42.970 & 13.588 & 6.0 \\
\hline Montefiore dell'Aso & $\mathrm{AP}$ & 43.051 & 13.751 & 6.0 \\
\hline Montefortino & FM & 42.942 & 13.342 & 6.0 \\
\hline Montegallo & $\mathrm{AP}$ & 42.841 & 13.333 & 6.0 \\
\hline Montegiorgio & FM & 43.130 & 13.537 & 6.0 \\
\hline Monteleone di Fermo & FM & 43.047 & 13.529 & 6.0 \\
\hline Montelparo & FM & 43.018 & 13.536 & 6.0 \\
\hline Montelupone & MC & 43.343 & 13.568 & 6.0 \\
\hline Montottone & FM & 43.062 & 13.585 & 6.0 \\
\hline Moregnano (Petritoli) & FM & 43.083 & 13.657 & 6.0 \\
\hline Morrovalle & MC & 43.314 & 13.580 & 6.0 \\
\hline Penna San Giovanni & MC & 43.056 & 13.426 & 6.0 \\
\hline Petriolo & MC & 43.221 & 13.466 & 6.0 \\
\hline Petritoli & FM & 43.067 & 13.656 & 6.0 \\
\hline Ponzano di Fermo & FM & 43.102 & 13.659 & 6.0 \\
\hline Potenza Picena & MC & 43.366 & 13.621 & 6.0 \\
\hline Rapagnano & FM & 43.161 & 13.593 & 6.0 \\
\hline Rosara (Ascoli Piceno) & AP & 42.838 & 13.539 & 6.0 \\
\hline San Ginesio & MC & 43.108 & 13.319 & 6.0 \\
\hline Santa Maria a Corte (Ascoli Piceno) & $\mathrm{AP}$ & 42.819 & 13.609 & 6.0 \\
\hline Sant'Angelo in Pontano & MC & 43.100 & 13.398 & 6.0 \\
\hline Sant'Elpidio a Mare & FM & 43.229 & 13.686 & 6.0 \\
\hline Valle Castellana & TE & 42.737 & 13.499 & 6.0 \\
\hline Altidona & FM & 43.109 & 13.798 & 5.5 \\
\hline Basciano & $\mathrm{TE}$ & 42.596 & 13.740 & 5.5 \\
\hline Caldarola & MC & 43.137 & 13.226 & 5.5 \\
\hline Campofilone & FM & 43.078 & 13.814 & 5.5 \\
\hline Castellalto & $\mathrm{TE}$ & 42.679 & 13.822 & 5.5 \\
\hline Colmurano & MC & 43.163 & 13.358 & 5.5 \\
\hline Comunanza & AP & 42.958 & 13.414 & 5.5 \\
\hline Grottammare & AP & 42.980 & 13.872 & 5.5 \\
\hline Grottazzolina & FM & 43.111 & 13.603 & 5.5 \\
\hline Lapedona & $\mathrm{FM}$ & 43.109 & 13.772 & 5.5 \\
\hline Montecassiano & MC & 43.363 & 13.436 & 5.5 \\
\hline
\end{tabular}

Table 1 (columns from left to right). List of intensity points after the reappraisal. pr: province (presently effective); D (Damage) indicates a single building damage without anyother information related to that locality; F (Felt) indicates a generic perception of the earthquake. 


\begin{tabular}{|c|c|c|c|c|}
\hline locality & $\mathrm{pr}$ & lat & long & I MCS \\
\hline Montegranaro & FM & 43.233 & 13.633 & 5.5 \\
\hline Montemonaco & $\mathrm{AP}$ & 42.899 & 13.326 & 5.5 \\
\hline Monteprandone & AP & 42.919 & 13.835 & 5.5 \\
\hline Monterubbiano & FM & 43.085 & 13.716 & 5.5 \\
\hline Osimo & AN & 43.484 & 13.488 & 5.5 \\
\hline Ripe San Ginesio & $\mathrm{MC}$ & 43.142 & 13.367 & 5.5 \\
\hline Teramo & $\mathrm{TE}$ & 42.659 & 13.704 & 5.5 \\
\hline Torre San Patrizio & FM & 43.184 & 13.608 & 5.5 \\
\hline Urbisaglia & $\mathrm{MC}$ & 43.196 & 13.377 & 5.5 \\
\hline Apiro & MC & 43.391 & 13.132 & 5.0 \\
\hline Belforte del Chienti & $\mathrm{MC}$ & 43.163 & 13.238 & 5.0 \\
\hline Camerino & MC & 43.135 & 13.068 & 5.0 \\
\hline Castelraimondo & $\mathrm{MC}$ & 43.209 & 13.057 & 5.0 \\
\hline Civitanova Marche & $\mathrm{MC}$ & 43.308 & 13.722 & 5.0 \\
\hline Cupra Marittima & AP & 43.024 & 13.859 & 5.0 \\
\hline Fiastra & $\mathrm{MC}$ & 43.037 & 13.157 & 5.0 \\
\hline Fontespina (Civitanova Marche) & $\mathrm{MC}$ & 43.328 & 13.716 & 5.0 \\
\hline Macerata & $\mathrm{MC}$ & 43.299 & 13.452 & 5.0 \\
\hline Monte Urano & AP & 43.202 & 13.673 & 5.0 \\
\hline Pievebovigliana & MC & 43.065 & 13.084 & 5.0 \\
\hline Porto Recanati & $\mathrm{MC}$ & 43.432 & 13.665 & 5.0 \\
\hline Porto San Giorgio & FM & 43.180 & 13.794 & 5.0 \\
\hline Pretare (Arquata del Tronto) & AP & 42.797 & 13.300 & 5.0 \\
\hline Recanati & $\mathrm{MC}$ & 43.405 & 13.561 & 5.0 \\
\hline Roseto degli Abruzzi & $\mathrm{PE}$ & 42.674 & 14.016 & 5.0 \\
\hline San Severino Marche & $\mathrm{MC}$ & 43.229 & 13.181 & 5.0 \\
\hline Sarnano & $\mathrm{MC}$ & 43.035 & 13.301 & 5.0 \\
\hline Serrapetrona & $\mathrm{MC}$ & 43.176 & 13.189 & 5.0 \\
\hline Smerillo & FM & 43.004 & 13.445 & 5.0 \\
\hline Tolentino & $\mathrm{MC}$ & 43.209 & 13.283 & 5.0 \\
\hline L'Aquila & AQ & 42.356 & 13.396 & 4.5 \\
\hline Bolognola & $\mathrm{MC}$ & 42.995 & 13.229 & $\mathrm{~F}$ \\
\hline Cingoli & MC & 43.374 & 13.203 & $\mathrm{~F}$ \\
\hline Esanatoglia & $\mathrm{MC}$ & 43.253 & 12.951 & $\mathrm{~F}$ \\
\hline Fiordimonte & $\mathrm{MC}$ & 43.037 & 13.088 & $\mathrm{~F}$ \\
\hline Fiuminata & $\mathrm{MC}$ & 43.188 & 12.933 & $\mathrm{~F}$ \\
\hline Gagliole & $\mathrm{MC}$ & 43.238 & 13.069 & $\mathrm{~F}$ \\
\hline Montecavallo & $\mathrm{MC}$ & 42.995 & 13.002 & $\mathrm{~F}$ \\
\hline Montecosaro & $\mathrm{MC}$ & 43.317 & 13.635 & $\mathrm{~F}$ \\
\hline Montefano & $\mathrm{MC}$ & 43.412 & 13.439 & $\mathrm{~F}$ \\
\hline Moresco & FM & 43.086 & 13.732 & $\mathrm{~F}$ \\
\hline Muccia & $\mathrm{MC}$ & 43.082 & 13.045 & $\mathrm{~F}$ \\
\hline Pedaso & FM & 43.100 & 13.842 & $\mathrm{~F}$ \\
\hline Pieve Torina & $\mathrm{MC}$ & 43.043 & 13.047 & $\mathrm{~F}$ \\
\hline Pioraco & $\mathrm{MC}$ & 43.180 & 12.987 & $\mathrm{~F}$ \\
\hline Pollenza & $\mathrm{MC}$ & 43.267 & 13.349 & $\mathrm{~F}$ \\
\hline San Benedetto del Tronto & AP & 42.936 & 13.887 & $\mathrm{~F}$ \\
\hline Sefro & $\mathrm{MC}$ & 43.146 & 12.949 & $\mathrm{~F}$ \\
\hline Serravalle di Chienti & $\mathrm{MC}$ & 43.073 & 12.953 & $\mathrm{~F}$ \\
\hline Treia & $\mathrm{MC}$ & 43.312 & 13.312 & $\mathrm{~F}$ \\
\hline Visso & $\mathrm{MC}$ & 42.930 & 13.088 & $\mathrm{~F}$ \\
\hline Palestrina & $\mathrm{RM}$ & 41.839 & 12.891 & 4.0 \\
\hline Pesaro & PU & 43.904 & 12.905 & 4.0 \\
\hline Poggio San Lorenzo & RI & 42.252 & 12.844 & 4.0 \\
\hline Rimini & $\mathrm{RN}$ & 44.059 & 12.567 & 3.0 \\
\hline Roma & $\mathrm{RM}$ & 41.895 & 12.482 & 3.0 \\
\hline
\end{tabular}

Table 1 (continued from previous page). 